\title{
A COMPARISON OF EMPLOYEES' PERCEIVED AND EXPECTED EMPLOYER BRAND ATTRIBUTES: EVIDENCE FROM TURKEY
}

\section{DOI: 10.17261/Pressacademia.2018.856 \\ PAP- V.7-2018(9)-p.57-61}

Hande Sinem Ergun ${ }^{1}$, Berivan Tatar ${ }^{2}$

${ }^{1}$ Marmara University, Göztepe Campus, 34722, Istanbul, Turkey. hsergun@gmail.com, ORCID: 0000-0003-3885-8902

${ }^{2}$ Gebze Technical University, 41400, Kocaeli, Turkey.

btatar@gtu.edu.tr, ORCID: 0000-0002-0934-3734

To cite this document

Ergun, H. S., Tatar, B. (2018). A comparison of employees' perceived and expected employer brand attributes: evidence from Turkey. PressAcademia Procedia (PAP), V.7, p.57-61.

Permemant link to this document: http://doi.org/10.17261/Pressacademia.2018.856

Copyright: Published by PressAcademia and limited licenced re-use rights only.

\section{ABSTRACT}

Purpose- The concept of employer brand has provided great convenience for creating a sense of "great place to work" in the war for talent in today's business world. In particular, employer brand perception meeting the employees' expectations has a critical prescription for retainment ability of employers. In this context, the aim of the study is to evaluate the congruence of expected and perceived employer brand.

Methodology- Data gathered from 300 employees in the banking sector was analyzed through SPSS and factor and reliability analysis and paired sample t-test were used to test hypotheses.

Findings- Results indicated that employers mostly provide social and application value and the highest difference occurs between perceptions and expectations of interest and economic value in the banking sector.

Conclusion- The study contributes to the comprehension of that using employer branding practices alone is not sufficient and compatibility of attributes with employees' expectations is essential for employer attractiveness.

Keywords: Employer brand, employer brand attractiveness, banking industry, employer brand expectation, employer brand perception. JEL Codes: M51, M12, L20

\section{INTRODUCTION}

Organizations, in today's business world, have experienced difficulties and challenges in attracting and retaining their potential and current employees because of competition for the limited talented workforce.

One of the important reasons for talent shortages is the aging of the population. Rosethorn (2009) stated that percentage of human population in the 15-64 age group will be $7 \%$ in Japan, $9 \%$ in Italy, 14\% in Japan and It is likely that this problem will emerge, in the near future, because of the one-child policy in China. Besides, 500 US largest companies have faced the risk of losing half of their senior managers in coming five years and workforce borning in baby-boomers' generations will leave off employment because of retirement. On the other hand, US has a risk of experiencing 10 million labor shortages by 2010 .

This talent scarcity revealed the fact that human resources are one of the most important sources for organizations and organizations. A vast number of organizations have used employer brand concepts and practices in order to be able to cope with this scarcity. Through the differentiated and unique employer brand experience created through these practices, retaining current employees and being the first choice of potential employees has been targeted by the organizations. In this context, another important point is fit, congruence and relevance of employer brand with values and needs of target group audiences. Knox and Freeman (2006) revealed that congruence between external and internal employer brand image lead to attractiveness. However, there is no study examining the potential gap between experienced and expected employer branding. With this regard, the aim of this study is to be one of the first study comparing actual and ideal aspects of employer branding.

In this context, studies on the employer brand will be summarized in the literature section of this study; in the next section, methods and findings will be revealed and the results will be evaluated. In the last part of the report, suggestions will be made for future studies. 


\section{LITERATURE REVIEW}

The war for talent stemming from changes in demographic, economic and social factors has brought challenges for organizations in attracting and retaining the talented employees. With this regard, employer brand concept has been developed as a solution for the difficulty of finding a qualified employee as a result of a talent shortages through applying the brand concept in the field of marketing to the field of human resources management.

Employer brand was firstly introduced by Ambler and Barrow (1996:188) and defined as "the package of functional, economic, and psychological benefits provided by employment, and identified with the employing company". In other words, organizations as an employer have provided benefits as monetary inducements, developmental opportunities, good working environment and recognition in exchange for effort, labor and skills of employees based on the mutual agreement in an employee-organization relationship.

Lievens and Highhouse (2003) adopted a symbolic and instrumental framework in marketing literature to determine the attractiveness of the employer side of the organization. Backhous and Tikoo (2004) revealed the two assets created with the employer branding as employer brand associations and brand loyalty. According to their employer brand framework, associations gathered from different resources of knowledge have shaped the employer brand image including functional and symbolic attributes of employer brand. The attractiveness of the employer brand will be in proportion to the power of these associations and, hence, the image of the employer brand.

Moroko and Uncles (2005) accentuated the similarity of consumer and corporate brand characteristics with employer branding in terms of being noticeable and known, seen as relevant and resonant, differentiated from direct competitors. Besides, Davies (2008) investigated that employer brand personality has affected the perceived differentiation, loyalty, satisfaction and affinity and agreeableness aspect of brand personality is the most important determinant of these outcomes.

Employer brand is the crucial conceptual framework by virtue of attracting and retaining the best talents. Benefits and core values provided through employer branding also contributes to satisfaction and commitment level of employees. High level of satisfaction and commitment leads to increase in customer satisfaction and loyalty.

\section{HYPOTHESIS DEVELOPMENT}

Attracting and retaining the best-talented employees is the crucial factors for gaining a competitive advantage because of talent shortages and a large number of organizations need to work with employees having similar skills, knowledge, and abilities. With this regard, organizations have developed differentiated and unique strategies for increasing their attractiveness.

Lievens and Highhouse (2003) stated that employer brand attractiveness of banks is mostly predicted by attributes of employer brand as innovativeness, competence, sincerity, advancement, and pay. Lievens (2007) investigated the employer brand perception of potential and actual applicants and current employees and found that symbolic attributes have an important role in employer brand attractiveness perception while instrumental attributes have no impact on the attracting current employees. Lievens, Van Hoye and Anseel (2007) demonstrated that symbolic attributes of employer brand are the best predictors of employees' identification and their perception of employer brand image instead of instrumental attributed of employer branding. Maxwell and Knox (2009) focused on what makes organizations attractive and motivate employees for "living the brand" and revealed that specific attributes as employment, organizational successes, construed external image, and product or service characteristics are the predictors of attractiveness. Schlager et al. (2011) examined the role of the symbolic and instrumental attribute on the attracting the current employees and ideal employer of the respondents on their organizational outcomes. Findings showed that employees expect social, diversity and reputation value for developing identification towards organizations while their perception of social and reputation value are determinants of identification and economic, development, social and diversity value are predictors of their satisfaction. Similarly, Wahba and Elmanadily (2015) investigated that agreeableness, enterprising and chic effect the satisfaction level of current employees from their jobs and employers.

On the other hand, organizations should balance the actual and desired values for the effectiveness of the employer brand by designating desired values and comparing them with experienced value. Based on this benchmarking, organizations, as an employer, should develop strategies for closing the potential gap for effectiveness and improvement of employer brand. In a nutshell, the success of employer brand in terms of luring the best possible and current talents has mainly determined by creating the congruence and fit perception between employers and employees of the organization (Backhaus and Tikoo, 2004). Based on these earlier findings, we compare the employer branding perception and expectation of employees for determining the attractiveness of the organization. Therefore:

$\mathrm{H} 1$ : There is the difference between perceived and expected application value aspect of employer branding

$\mathrm{H} 2$ : There is the difference between perceived and expected economic value aspect of employer branding.

H3: There is the difference between perceived and expected development value aspect of employer branding.

$\mathrm{H} 4$ : There is the difference between perceived and expected social value aspect of employer branding.

H5: There is the difference between perceived and expected interest value aspect of employer branding. 


\section{DATA AND METHODOLOGY}

\subsection{Sample and Data Collection}

Data used in the study have been collected through a self-administered questionnaire and convenient sampling technique. With this regard, the data obtained from 300 respondents in the banking sector were analyzed by using SPSS 21.0 Statistical Package Program. Descriptive statistics, factor analysis, reliability analysis and paired sample t-test have been used in the analyses of the data.

Participants' ages ranged from 22 to 51 years. The average age of the sample is 31.1 . It is seen that $45.8 \%$ of the participants were female (137) and $54.2 \%$ were male (162). In terms of education, it was seen that 2,8\% of respondents were graduated from high school (8), $8.7 \%$ of respondents were graduated from vocational high school (26), 49.5\% of respondents were graduated from university bachelor's degree (139) and $31,7 \%$ of them have a master' degree (95) and 4.6 of them were graduated with doctorate degree (13). the average of work experience of respondents in the current organization have been 3,08 years and total job tenure of respondents have been 5,57 years.

\subsection{Measures}

Survey technique has been used to collect research data. The questionnaire consists of 55 questions and three main parts; perceived and expected employer branding scales and questions to determine the demographic structure of the respondents. Six -point Likert scale was used for all scales ranging from "I totally disagree" to "I totally agree". The Employer Attractiveness scale (EmpAt scale) developed by Berthon, Ewing and Hah (2005) has been used for measuring employer branding with 25 items. EmpAt Scale has composed of five subdimensions as application value, economic value, development value, social value and interest value. Items in the scale adopted according to perception and expectation measurements.

\section{FINDINGS}

\subsection{Factor and Reliability Analysis}

Factor analysis was used to determine the construct validity of the scales used in the study. In the Exploratory Factor Analysis, the principal component analysis method and the varimax rotation technique were performed for determining the factor loadings for all scales and the factor loads greater than 0.50 were considered in the analyses.

Table 1: Result of Factor and Reliability Analysis for Expected Employer Branding

\begin{tabular}{|c|c|c|c|c|c|c|c|}
\hline Factors & $\begin{array}{l}\text { Number } \\
\text { of items }\end{array}$ & $\begin{array}{c}\text { Factor } \\
\text { Loadings }\end{array}$ & $\begin{array}{c}\% \text { of } \\
\text { Variance }\end{array}$ & $\begin{array}{c}\text { Cronbach } \\
\alpha \\
\end{array}$ & KMO & $x^{2}$ & p \\
\hline Application Value & 7 & ,740-,602 & 20,731 & 903 & \multirow{3}{*}{,946 } & \multirow{3}{*}{4079,461} & \multirow{3}{*}{,000 } \\
\hline Development Value & 4 & ,752-,569 & 15,589 & , 858 & & & \\
\hline Social Value & 3 & ,816-,540 & 11,181 & ,787 & & & \\
\hline
\end{tabular}

As a result of the exploratory factor analysis applied to the employer branding scale used for measuring expectation of respondents, a total of 4 items were extracted from the analysis because of cross-loading and lower loadings $(<0.50)$. Factor analysis with the remaining 21 items resulted in a 5 -factor structure that accounts for $71,962 \%$ of the total variance. Finally, the KMO value of scale was, 946 and the Barlett Sphericity Test was significant (Sig. = ,000). In the reliability analysis, the reliability values of scales ranged from ,767 to ,903.

Table 2: Result of Factor and Reliability Analysis for Perceived Employer Branding

\begin{tabular}{|c|c|c|c|c|c|c|c|}
\hline Factors & $\begin{array}{l}\text { Number } \\
\text { of items }\end{array}$ & $\begin{array}{c}\text { Factor } \\
\text { Loadings }\end{array}$ & $\begin{array}{c}\% \text { of } \\
\text { Variance }\end{array}$ & $\begin{array}{c}\text { Cronbach } \\
\alpha\end{array}$ & KMO & $x^{2}$ & $\mathbf{p}$ \\
\hline Application Value & 3 & $.836-, 645$ & 13,065 & 797 & \multirow{3}{*}{,949 } & \multirow{3}{*}{5517,560} & \multirow{3}{*}{, 000 } \\
\hline Development Value & 3 & ,818-,718 & 15,041 & 909 & & & \\
\hline Social Value & 2 & ,771-,727 & 11,853 & ,869 & & & \\
\hline
\end{tabular}

According to Table 2, it was found that the value of Kaiser-Meyer-Olkin Measure of Sampling Adequacy (KMO) is ,954 and the result of The Barlett Sphericity test was significant $(p=0,000)$ for the employer branding scale used for measuring expectation of respondents. In the exploratory factor analysis, firstly, 5 factors structure emerged accounting for $75,849 \%$ of the total variance. A total of 4 items were extracted from the analysis because of cross-loading and lower loadings $(<0.50)$. Factor analysis with the remaining 21 items resulted in a 5 -factor structure that accounts for $77,939 \%$ of the total variance. Finally, the KMO value of scale was, 949 and the Barlett Sphericity Test was significant (Sig. $=, 000$ ). In the reliability analysis, the reliability values of scales ranged from ,797 to 0.959 . 


\subsection{Results of Paired Sample T-Test}

As a result of factor and reliability analysis, the dimensions of factors affecting employer brand have been determined. The Paired Sample t-test results have been shown in Table 3 .

\section{Table 3: Paired Sample T-Test Analysis Results for Employer Branding}

\begin{tabular}{|l|c|c|c|c|c|c|c|}
\hline & \multicolumn{2}{|c|}{ Expectations } & \multicolumn{2}{c|}{ Perceptions } & \multirow{2}{*}{ Mean dif. } & \multirow{2}{*}{ T } & \multirow{2}{*}{ P } \\
\cline { 2 - 6 } & Mean & S.D. & Mean & S.D. & & &, 000 \\
\hline Application Value & 5,394 &, 716 & 4,675 &, 873 & 0,719 & 13,158 &, 000 \\
\hline Economic Value & 5,622 &, 579 & 4,427 & 1,005 & 1,195 & 18,939 &, 000 \\
\hline Development Value & 5,447 &, 738 & 4,513 &, 951 & 0,934 & 15,224 &, 000 \\
\hline Social Value & 5,562 &, 719 & 4,985 &, 822 & 0,577 & 11,611 &, 000 \\
\hline Interest Value & 5,487 &, 658 & 4,230 & 1,153 & 1,257 & 17,448 &, \\
\hline
\end{tabular}

According to the results of the Paired Samples $t$-test, $t$ is determined that there is a difference between the perceived and the expected factors of employer branding $(p<, 001)$. It is observed that Employees' perceptions have remained under their expectations of the employer branding.

For the expectation aspect of employer branding, results have shown that employees have expected from employer brand to be based on economic value (Mean score $=5,662$ ) and social value (Mean score $=5,562$ ). On the other hand, respondents have expected application value (Mean score $=5,394$ ) and development value (Mean score $=5,644$ ) less than other aspects of the employer branding. In terms of experienced employer branding, social value (Mean score $=4,985$ ) and application value (Mean score $=4,675$ ) have been becoming prominent in accordance with other factors. These results have shown that employees have experienced social and application value based employer brand in their organization. In this context, it is seen that the greatest difference has existed between perceived and expected value of interest value (Mean difference $=1,257$ ) and economic value (Mean difference $=1,195$ ) factors of the employer brand.

\section{CONCLUSION}

In today's business world, aging population, changes in social, demographic and technological factors have led organizations to a search for ways of retaining current employees as well as attracting the potential employees. In this context, organizations need to increase their attractiveness with differentiated and unique employer brand practices. Besides, the needs, values, and personalities of the employees should be taken into consideration in the process of determining these employer brand practices and the existing employer brand attributes must be relevant with the needs and expectations of the employees for attracting and retaining them in the organization (Moroko and Uncles, 2005). Verquer, Beehr and Wagner, (2003) accentuated that similarities of values, goals personality of organizations and their employees may lead to desirable employees' outcomes. In this point, organizational processes such as inducements, promotions, decision making need to be relevant and complementary of the employees' needs with regard to needs-structure fit. The lack of compliance and fit will create a gap and inconsistency between the ideal employer brand profile and the current employer profile they experience in the minds of employees.

In the light of all discussion mentioned above, this study aims to determine the potential gap between perceived and expected employer branding. Results of the study have shown that expectation of employees from the employer branding has not been met by the organization. The difference and gap between two sides of employer branding. The greatest gap has occurred in interest value aspect of employer branding. Employers are seeking to work with an employer having economic value based employer brand while current employers are applying social value-oriented employer branding practices. As a result, organizations should consider the expectation of employees from the employer branding and prevent this gap for increasing effectiveness and attractiveness of employer branding.

This study has some limitations because of gathering data from only the Kocaeli and İstanbul province of Turkey. The research was not conducted on a large sample due to time constraints and some difficulties during the collection of data. This affects the generalization of the study. For the future research, the effect of this gap between expected and perceived employer branding on the employees' organization outcomes as an intention to leave, commitment and satisfaction can be examined for contributing the literature.

\section{REFERENCES}

Backhaus, K., Tikoo, S. (2004). Conceptualizing and researching employer branding. Career development international, vol. 9, no. 5, pp. 501-51.

Barrow, S., Mosley, R. (2005). The employer brand. England: John Wiley\&Sons Ltd, pp. 132-145.

Berthon, P., Ewing, M., Hah, L. L. (2005). Captivating company: dimensions of attractiveness in employer branding. International journal of advertising, vol. 24, no. 2, pp. 151-172.

Biswas, M. K., Suar, D. (2014). Antecedents and consequences of employer branding. Journal of Business Ethics, pp. 1-16.

Cable, D. M., Judge, T. A. (1996). Person-organization fit, job choice decisions, and organizational entry. Organizational behavior and human decision processes, vol. 67, no. 3, pp. 294-311. 
Charbonnier-Voirin, A., Poujol, J. F., Vignolles, A. (2016). From value congruence to employer brand: impact on organizational identification and word of mouth. Canadian Journal of Administrative Sciences/Revue Canadienne des Sciences de I'Administration.

Elving, W. J., Westhoff, J. J., Meeusen, K., Schoonderbeek, J. W. (2013). The war for talent? The relevance of employer branding in job advertisements for becoming an employer of choice. Journal of Brand Management, vol. 20, no. 5, pp. 355-373.

Gaddam, S. (2008). Modeling employer branding communication: the softer aspect of HR marketing management. ICFAI Journal of Soft Skills, vol.2, no.1.

Knox, S., Freeman, C. (2006). Measuring and managing employer brand image in the service industry. Journal of Marketing Management, 22(7-8), 695-716

Lievens, F. (2007). Employer branding in the Belgian Army: the importance of instrumental and symbolic beliefs for potential applicants, actual applicants, and military employees. Human Resource Management, vol. 46, no. 1, pp.51-69.

Lievens, F., Van Hoye, G., Anseel, F. (2007). Organizational identity and employer image: towards a unifying framework. British Journal of Management, vol. 18, no. 1, pp. 45-S59.

Lievens, F., Highhouse, S. (2003). The relation of instrumental and symbolic attributes to a company's attractiveness as an employer. Personnel Psychology, vol. 56, no. 1, pp. 75-102.

Moroko, L., Uncles, M. D. (2008). Characteristics of successful employer brands. Journal of Brand Management, vol. 16, no. 3, $160-17$.

Maxwell, R., Knox, S. (2009). Motivating employees to" live the brand": a comparative case study of employer brand attractiveness within the firm. Journal of marketing management, vol. 25, no.9-10, pp. 893-907.

Rosethorn, H. (2009). The employer brand: keeping faith with the deal. Gower Publishing, Ltd.

Schneider, B. (1987). The people make the place. Personnel psychology, vol. 40, no.3, pp.437-453.

Verquer, M. L., Beehr, T. A., Wagner, S. H. (2003). A meta-analysis of relations between person-organization fit and work attitudes. Journal of vocational behavior, vol. 63, no. 3, pp.473-489.

Wahba, M., Elmanadily, D. (2015). Employer branding impact on employee behavior and attitudes applied study on pharmatecual in Egypt. International Journal of Management and Sustainability, vol. 4, no.6, pp. 145 